\title{
Meningococcal Vaccines: Current Status and Emerging Strategies
}

\author{
Pumtiwitt C. McCarthy * (1), Abeer Sharyan and Laleh Sheikhi Moghaddam \\ Department of Chemistry, Morgan State University, Baltimore, MD 21251, USA; absha3@morgan.edu (A.S.); \\ lashe9@morgan.edu (L.S.M.) \\ * Correspondence: Pumtiwitt.McCarthy@morgan.edu; Tel.: +1-443-885-3882
}

Received: 30 January 2018; Accepted: 23 February 2018; Published: 25 February 2018

\begin{abstract}
Neisseria meningitidis causes most cases of bacterial meningitis. Meningococcal meningitis is a public health burden to both developed and developing countries throughout the world. There are a number of vaccines (polysaccharide-based, glycoconjugate, protein-based and combined conjugate vaccines) that are approved to target five of the six disease-causing serogroups of the pathogen. Immunization strategies have been effective at helping to decrease the global incidence of meningococcal meningitis. Researchers continue to enhance these efforts through discovery of new antigen targets that may lead to a broadly protective vaccine and development of new methods of homogenous vaccine production. This review describes current meningococcal vaccines and discusses some recent research discoveries that may transform vaccine development against $N$. meningitidis in the future.
\end{abstract}

Keywords: Neisseria meningitidis; glycoconjugate vaccines; protein-based vaccines; vaccine development

\section{Introduction}

Neisseria meningitidis is a leading cause of bacterial meningitis. According to the World Health Organization, the disease has a high mortality rate (up to $50 \%$ if left untreated) and can leave $10 \%$ of those who do survive with devastating sequelae such as deafness and loss of limbs [1]. Most cases of the disease affect children under the age of 2 and between the ages of 16-21 [2]. It is estimated that one-third of disease cases affect those 65 or older. At least 12 different N. meningitidis serogroups have been identified, based on the chemical composition of their polysaccharides [3]. Six of these serogroups cause disease: serogroups A, B, C, W, X and Y. While most cases of meningococcal meningitis are sporadic, outbreaks still occur. Certain serogroups predominate in specific global regions [4]. Epidemics of disease caused by N. meningitidis serogroup A (MenA) occur in the meningitis belt of sub-Saharan Africa as well as southeastern Asia. This region of sub-Saharan Africa includes 22 countries and extends from Ethiopia to Senegal. Serogroups B and C (MenB, MenC) are responsible for most disease in Europe and North America. Disease caused by serogroup W (MenW) is common in parts of Africa and South America. It is responsible for an epidemic that occurred during the Hajj pilgrimage to Mecca nearly two decades ago. N. meningitidis serogroup Y (MenY) has been increasing in incidence in North America and Europe. Finally, serogroup X (MenX) is increasingly being reported in regions of Africa. Immunization strategies against those serogroups for which there are vaccines (there is currently no vaccine against serogroup $X$ ) have been crucial in helping to decrease the incidence of meningococcal meningitis [4]. This review aims to provide information on the currently licensed meningococcal vaccines and discuss some recent research discoveries that may help improve meningococcal vaccine production in the future. 


\section{Current Vaccines against Neisseria meningitidis}

\subsection{Polysaccharide-Based Vaccines}

There are effective vaccines for five of the six disease-causing serogroups of Neisseria meningitidis (A, B, C, W and Y). There are polysaccharide-based and glycoconjugate vaccines for serogroup A, C, $\mathrm{W}$ and $\mathrm{Y}$ [5]. Serogroup B is targeted by a protein-based vaccine [6]. The currently administered polysaccharide-based vaccines are quadrivalent containing capsular polysaccharide from serogroups A, C, W and Y. Monovalent (targeting serogroups A and C) and trivalent (targeting serogroups A, C and W) vaccines are no longer used. Once quadrivalent vaccines were licensed, these were administered instead of monovalent and trivalent. Mencevax (GlaxoSmithKline, Belgium) is licensed for use in Europe while Menomune (Sanofi Pasteur, Swiftwater, PA, USA) is licensed for use in the United States and Canada. Polysaccharide vaccines are composed of purified capsular polysaccharides obtained directly from the particular serogroup of the pathogen. Polysaccharide vaccines are primarily used in cases of epidemics and outbreaks [7]. A short-lived, T cell-independent immune response is generated from immunization with this class of vaccines. Conjugate vaccines elicit longer-lasting immune responses [8]. As a result, this is the major class of vaccine used to combat $N$. meningitidis serogroups $\mathrm{A}, \mathrm{C}, \mathrm{W}$ and $\mathrm{Y}$ [1].

\subsection{Glycoconjugate Vaccines}

Carbohydrate-based glycoconjugate vaccines use microbial capsular sugars covalently linked to a carrier protein [9]. After isolation of purified meningococcal capsular polysaccharide, it is subjected to acid hydrolysis to obtain smaller oligosaccharide fragments [10]. The resulting products are separated using chromatographic methods to obtain a particular size population for the intended vaccine. Three major types of carrier proteins have been used in vaccines against Neisseria meningitidis: diphtheria toxoid (DT), cross-reacting material of diphtheria toxoid with an amino acid 197 substitution which renders it inactive (CRM197), and tetanus toxoid (TT) [11]. All of these carrier proteins are inactivated forms of protein toxins from the bacterial pathogens. Corynebacterium diphtheriae is the source of DT and CRM197 while Clostridium tetani is the source of TT. The carrier proteins are crucial to inducing B cells and T cell-dependent immune responses leading to immune memory. To bring the oligosaccharides and protein together to make the vaccine, both are chemically modified to contain complementary groups that are crosslinked under proper conditions [10]. One disadvantage of this type of coupling is the resulting heterogeneity. Recent research has sought ways to make vaccine production more homogenous (discussed later). Current meningococcal conjugate vaccines are available in monovalent, quadrivalent and combination forms. These vaccines target specific age groups based on epidemiological data on disease incidence and efficacy is confirmed through clinical testing [12].

\subsubsection{Monovalent Conjugate Vaccines}

There are currenty three monovalent conjugate vaccines licensed for N. meningitidis serogroup C and one monovalent vaccine against serogroup A. Two of the serogroup $C$ vaccines (Meningtec from Pfizer (New York, NY, USA) and Menjugate from GlaxoSmithKline (Brentford, UK) use CRM197 as a carrier protein, while the other (NeisVac-C by Pfizer, Kirkland, Canada) uses TT. All three vaccines are effective in infants 2 months and younger [2]. A low-cost monovalent serogroup A vaccine with TT as carrier protein (MenAfriVac by Serum Institute of India) was developed for the meningitis belt of sub-Saharan Africa. This conjugate vaccine was produced through a unique collaboration between industry and government partners specifically the U.S. Food and Drug Administration, the Bill and Melinda Gates Foundation-funded Meningitis Vaccine Project/PATH foundation, the World Health Organization and the Serum Institute of India $[13,14]$. This vaccine has a broader targeted age group of ages 1-29 years old [13]. 


\subsubsection{Quadrivalent Conjugate Vaccines}

Conjugate vaccines containing capsular sugars from four serogroups naturally provides broader coverage than the monovalent vaccines. They also, for the most part, cover a wider range of age groups. There are three licensed quadrivalent vaccines and each of the three carrier proteins are represented [15-17]. Menveo (GlaxoSmithKline, Brentford, UK) contains CRM197 as a carrier protein. Different formulations of the vaccine are effective for ages 2-23 months, 2-10 years and 11-55 years. Menactra (Sanofi-Pasteur) is a conjugate vaccine of DT with a similar age group coverage (9-23 months, 2-10 years and 11-55 years). Nimenrix (Pfizer, New York, NY, USA) is a conjugate containing TT. This particular vaccine has a narrower age range (12 months or younger). GlaxoSmithKline produces combination conjugate vaccines (described below) with broader effective age ranges.

\subsubsection{Combined Conjugate Vaccines}

MenHibrix (Hib-MenCY-TT) and Menitorix (Hib-MenC-TT) are conjugate vaccines that are protective against serogroups of certain N. meningitidis serogroups and Hemophilus influenza b (Hib) [18]. Hib is a Gram-negative bacteria that causes pneumonia and meningitis in children under the age of five [19]. It is the first target for which a successful conjugate vaccine was developed for [20]. MenHibrix and Menitorix contain polyribosylribitol phosphate which is a major component of the capsule of Haemophilus influenzae b (Hib). MenHibrix targets ages 6 weeks to 18 months old. There is a two vaccine dose for Menitorix. The first dose is effective for ages 6 weeks to 12 months and the second dose is effective for ages 12 months to 2 years.

\subsection{Outer Membrane Vesicle-Based and Protein-Based Vaccines}

Glycoconjugate vaccine strategies against serogroup B have not been pursued aggressively due to self-antigen concerns. Capsular polysaccharide from this serogroup is comprised of $\alpha, 2-8$ linked sialic acid, the same linkage of polysialic acid found on the mammalian neural cell adhesion molecule [21]. Glycoconjugates using modified sialic acid, N-propionylated sialic acid, were used in some clinical studies but those have not advanced to the licensing stage [22-25]. The first non-glycan-based vaccine against Neisseria meningitidis serogroup B was an outer membrane vesicle-based (OMV) vaccine licensed in Cuba [26]. OMVs are naturally occurring vesicles released by Gram negative bacteria. They contain phospholipids, lipooligosaccharides, and membrane proteins. All of those components alone can be antigens that are recognized by host antibodies. OMV vaccines can act as a self-adjuvant. VA-MENGOC-BC (Finlay Institute, Havana, Cuba) was first licensed for use in Cuba in 1987 [21]. It is comprised of OMV from a strain of the bacteria that was responsible for an epidemic in that nation. It is also contains polysaccharide from serogroup $C$ and is therefore protective against both serogroups.

Two other OMV/protein-based vaccines targeting serogroup B have also been introduced. Protein targets for serogroup B were discovered using the concept of reverse vaccinology for the first time $[27,28]$. Reverse vaccinology essentially starts with a genomic search for potential antigens and the use of recombinant DNA technology to produce and test these antigens for suitability [29]. This circumvents the need to grow a specific pathogen to obtain antigens. This technology has led to licensing of Bexsero (GlaxoSmithKline, Verona, Italy) and Trumenba (Wyeth, Philadelphia, PA, USA) [6]. Bexsero, contains OMV from NZ98/254 (an outbreak-specific strain), rNHBA (a recombinant Neisseria heparin binding antigen) fusion protein, $\mathrm{rNadA}$ (recombinant Neisseria adhesin $\mathrm{A}$ ), $\mathrm{rfHbp}$ (a recombinant complement factor $\mathrm{H}$ binding protein). Trumenba, on the other hand, is composed of two lipidated antigenic variants of rfHbp factors. 


\section{Emerging Methods of Vaccine Production}

\subsection{Chemical and Chemoenzymatic Synthesis of Oligosaccharides}

Research efforts have evolved toward production of homogeneous glycoconjugate vaccines against $N$. meningitidis and other bacterial pathogens (recently reviewed here [30]). Current manufacturing methods for meningococcal glycoconjugate vaccines involve attachment of carbohydrate fragments to modified carrier proteins. These methods can suffer from issues such as exposure to pathogenic bacteria and low conjugation ratios [31]. Production of homogeneous meningococcal glycoconjugates are advantageous because they can circumvent such issues. This should allow for better assessment of the relationship between vaccine structure and immune response generated. In this vein, meningococcal carbohydrate antigens have been produced by chemical or chemoenzymatic synthesis. These routes are superior to isolation from the bacteria because there is no interaction with pathogenic materials and there can be better control of the carbohydrate produced. The typical method for obtaining vaccine capsular oligosaccharides for conjugation is acid hydrolysis of the isolated polysaccharide and sizing using chromatography. In complete chemical synthesis, carbohydrate chemists can adjust their chemical schemes to reach their targeted length. Chemoenzymatic synthesis requires optimization of glycosyltransferase chemical properties (i.e., by genetic mutation) and particular reaction conditions to obtain a desired target population of products. Additionally, both methods may allow for synthesis of products that mimic carbohydrate structure that can then be tested for immunoreactivity [32]. Oligosaccharides produced from chemical or chemoenzymatic methods are then conjugated to carrier proteins to produce glycoconjugate vaccine candidates. These candidates are used to immunize mice and the antibody titers are assessed for reactivity against the specific carbohydrate serogroup. Antibodies are also evaluated for their ability to kill the bacterial pathogen of interest. Activity in the serum bactericidal antibody (SBA) assay is considered to be a correlate of immune protection [33].

There are a few published studies where meningococcal oligosaccharides were chemically synthesized and conjugated to a carrier protein for immunization. Chemical structures of the monosaccharide units of meningococcal polysaccharides for which there are currently glycoconjugate vaccines are given in Figure 1. The Wu group synthesized different chain lengths (degrees of polymerization, DP) of serogroup W capsule oligosaccharides. The serogroup W capsular polysaccharide contains repeating units of galactose and sialic acid. Each unit of galactose and sialic acid are linked together through an $\alpha$-glycosidic linkage between carbon 1 of galactose and carbon 4 of sialic acid. The units are linked to one another through an $\alpha$-glycosidic linkage carbon 2 of sialic acid and carbon 6 of galactose. Researchers from the Wu group chemically synthesized different oligosaccharides containg 1 galactose-sialic acid unit (DP2), 2 repeating units (DP4), 3 repeating units (DP6), 4 repeating units (DP8) and 5 repeating units (DP10) [34]. All of these were attached to carrier protein and used to immunize mice. Serum bactericidal antibodies were raised upon immunization with vaccine candidates containing DP4-DP10 while this wasn't seen for DP2. These results suggest that 2 repeating units are the minimum unit required to obtain immunogenicity. Similarly, the Misra group synthesized an oligosaccharide that contained 4 units of $\alpha, 1-6$ linked, $N$-acetyl-3-O-acetyl-D-mannosamine [35]. This is the monomer unit of serogroup A capsular polysaccharide. When conjugated to TT as a carrier protein, researchers obtained antibodies capable of killing N. meningitidis serogroup A after immunization. The Guo group successfully performed chemical synthesis of sialic acid oligomers up to DP2-DP5 containing $\alpha-2,9$ linked sialic acid. These were conjugated to two proteins (keyhole limpet hemocyanin and human serum albumin) and used to immunize mice [36]. Resulting antibodies were able to bind to $N$. meningitidis serogroup $\mathrm{C}$ bacteria suggesting recognition of the polysaccharide antigen in vivo.

The field of chemoenzymatic synthesis of Neisseria meningitidis oligosaccharides is where most recent research efforts have been focused. At this point in time, all of the glycosyltransferases responsible for synthesis of the capsular polysaccharides in disease-causing serogroups have been 
expressed in recombinant form [37-44]. The Vann group used modified acceptors to produce oligosaccharides from $N$. meningitidis serogroup $C$ that were conjugated to the Hc fragment of TT using site-specific chemistry [45,46]. Mice were immunized with vaccine candidates and the antibodies produced were immunoreactive with serogroup $C$ polysaccharide. Additionally, chemoenzymatic synthesis of potential vaccine components has been performed using Neisseria serogroups A, X, W and $Y[42-44,47]$. Recently, the Gerardy-Schann group has made significant advances in this regard. Her group has produced a conjugate vaccine using a recombinant form of the serogroup X capsule polymerase. Enzymatically-produced oligosaccharides were produced and conjugated to CRM197 using novel conjugation chemistry. The antibodies produced from immunization were found to be active in a serum bactericidal assay. In very recent work, her laboratory has optimized a solid-phase method with immobilized glycosyltransferases to produce oligosaccharides for serogroup A and X [48]. Using genetic engineering, the enzymes were optimized to produce products of a particular population of oligosaccharide chain lengths.

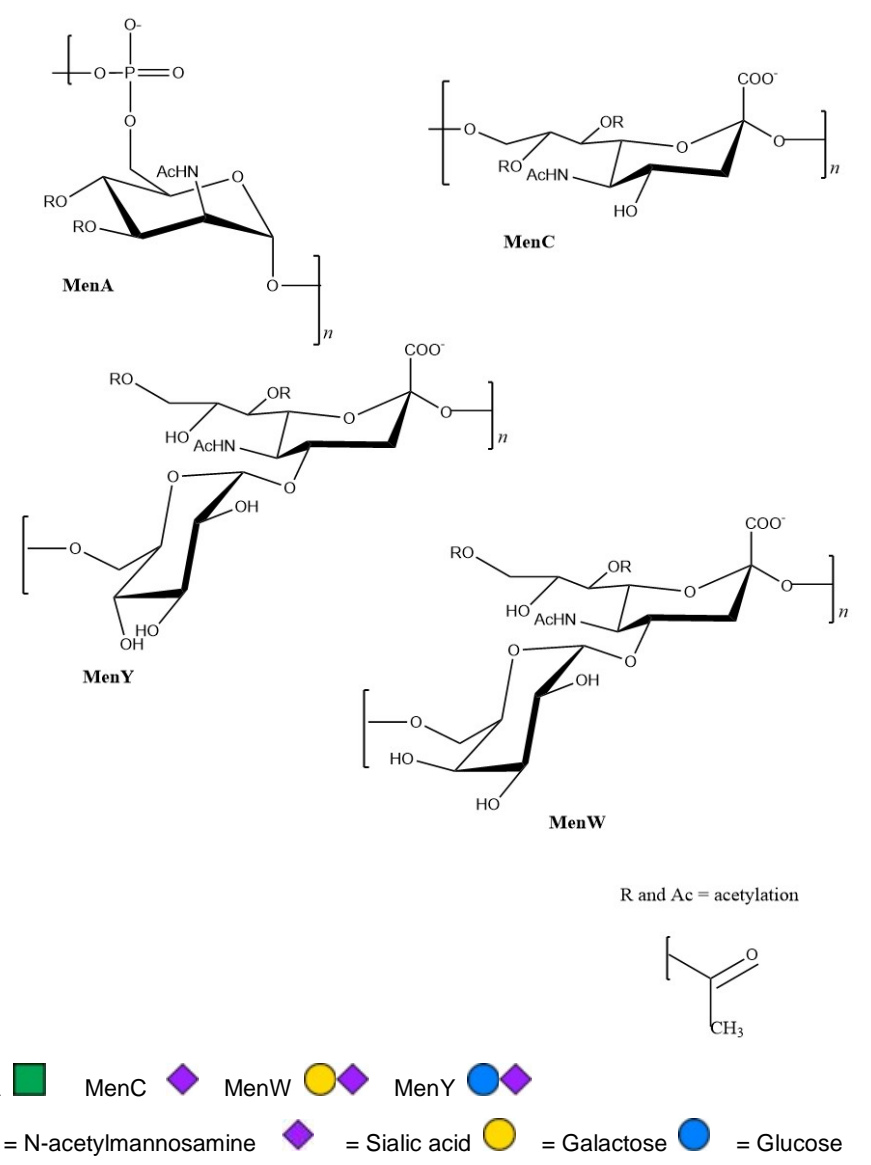

Figure 1. Chemical structures of monosaccharide units of meningococcal polysaccharides for which there are currently glycoconjugate vaccines. Sites of potential O-acetylation is indicated by $\mathrm{R}$ groups. The monosaccharide symbols follow the Symbol Nomenclature for Glycans (SNFG) according to [49].

\subsection{New Potential Carrier Proteins}

There are three carrier proteins, as described above, that have been used in Neisseria meningitidis glycoconjugate vaccines. Two other carriers have been used in other glycoconjugate vaccines [9]. The outer membrane protein complex of MenB has been used in the Hib conjugate vaccine. Protein D from non-typeable Haemophilus influenzae has been used in a multivalent pneumococcal vaccine. A recent study investigated 28 potential carrier proteins from different types of bacteria [50]. These proteins were conjugated to a model polysaccharide and of those, eight were selected as 
potential carriers for $N$. meningitidis. Of those, four were found to elicit antibodies in mice that were immunoreactive against MenC and one was found to elicit antibodies against MenA, MenC, MenW, MenY and MenX. This carrier protein obtained from Streptococcus pneumoniae could be further optimized as a new carrier protein.

\subsection{Advances in Lipopolysaccharides and Outer Membrane Vesicles as Vaccine Targets}

A broadly protective Neisseria vaccine would greatly advance the fight against meningitis. Serogroup-specific vaccines are the only type of vaccines currently available against Neisseria meningitidis. Vaccines with broad protection could target all serogroups by containing an antigen that is shared among them. Common proposed targets have been lipopolysaccharide and outer membrane vesicles. Lipopolysaccharide, also known as LPS or endotoxin, is a lipid and carbohydrate containing molecule anchored in the outer membrane of Gram negative bacteria. It is considered to be a virulence factor in the disease. Lipopolysaccharide contains three components: Lipid A, core oligosaccharides and O-antigen polysaccharide. Neisseria meningitidis contains lipooligosaccharides which contain only Lipid A and core oligosaccharides. These structures are common to all Neisseria species so lipooligosaccharides may be a useful target for the development of a broad vaccine [51]. One potential candidate for exploration comes from the work of Seeberger's group [52]. These researchers chemically synthesized a tetrasaccharide from the core oligosaccharide, conjugated it to a carrier protein and assessed the antibody response generated. This work revealed a key tetrasaccharide as a candidate for further study.

Outer membrane vesicles (OMVs) have been investigated for many years for vaccine development [53]. Recent work has sought to make OMVs more tractable as potential candidates by decreasing the toxicity of the LPS it contains. Deletion of specific genes of the LPS biosynthetic pathway (such as lpxL1) has led to production of OMVs with drastically reduced toxicity [54-56] . Additionally, genetic alterations have been explored to increase OMV production [56]. These have been explored as new candidates in pre-clinical trials of OMV-based vaccine candidates.

\subsection{Novel Protein Targets}

With the successful introduction of the two protein-based vaccines for $N$. meningitidis serogroup B, alternate protein targets have also been investigated. Porin protein A and porin protein B have long been proposed as targets for serogroup B $[57,58]$. These proteins are essential for pathogenesis and can occur in different ratios in different strains. Recent work by the Bash group has indicated some key elements of the porin protein structure that may serve as the minimum length required to obtain immunogenicity [59]. Other novel protein targets have been discovered using genomic, transcriptomic and proteomic approaches (reviewed here [54]). These targets are usually putative proteins believed to be expressed on the surface of the bacteria. One protein, macrophage infectivity potentiator protein has been investigated as a potential new target for serogroup B because it is conserved among strains $[60,61]$. The recombinant form of the protein was obtained and a liposome bound form of the protein was more immunogenic than a control and alum adjuvanted delivery of the protein [62]. The Christodoulides research group has recently investigated an adhesin protein and an ABC transporter protein as potential protein targets for a broadly protective vaccine $[63,64]$. Bacterial adhesins are essential proteins to facilitate host-microbe binding. Transporter proteins of the ABC type couple the energy release of ATP hydrolysis to small molecule transport across the cell membrane. The group determined that a putative N. meningitidis serogroup B amino acid ABC transporter, NMB1612 (in the presence of adjuvant or in liposomes), can successfully elicit bactericidal antibodies. These antibodies can also target different disease-causing strains. A similar trend was seen with adhesin proteins. Other investigated targets that are predicted to be cytoplasmic proteins in high levels in outer membrane vesicles are: NMB0928 and NMB0088 [65,66]; recombinant lipidated transferrin protein [67], RmpM protein [68,69], and heat-shock/chaperonin 60 [70](which may serve as candidate for broad protection). 


\subsection{Nanoparticulate Vaccine Delivery}

Nanoparticulates are small nanoscale spherical compounds that have antigens either covalently attached, embedded non-covalently to the surface or fully encapsulated by the particulate (reviewed here [71]). All of these forms are meant to mimic how a pathogen presents antigen to a host. The types that have been explored for general vaccine use are virus like particles, liposomes, immune stimulating complexes, polymeric nanoparticles, nondegradable nanoparticles. Most alternate delivery studies for $N$. meningitidis have focused on liposomes [62,67,68,72-75]. Liposomes contain a lipid bilayer or double lipid bilayer. The interior of the liposome provides an aqueous compartment for the antigen.

The Mekalanos group has done work with components of the bacterial type IV secretion systems (T6SS) [76]. These systems are responsible for moving proteins between effector cells and target cells. Cytoplasmic sheaths containing heterodimers of VipA-VipB proteins from T6SS were recombinantly expressed and fused to the $N$. meningitidis serogroup B protein antigen $\mathrm{fHbp}$. These $\mathrm{fHbp}$-fused sheaths were used to immunize mice. The researchers observed the highest immune response with $\mathrm{fHbp}$-fused sheaths. This response was greater than antibody levels obtained from mice immunized with free sheaths or free fHbp. Additionally, the fused sheaths produced a greater response than mice immunized with free $\mathrm{fHbp}$ and free sheaths combined in one injection. Thus, fusion of antigens to these VipA-VipB sheaths may offer a new route of nanoparticulate vaccine delivery.

Recent work from researchers at GlaxoSmithKline has sought to transform delivery of the vaccine from an intramuscular injection to delivery through the dermis of the skin [77]. One advantage of this route is that the skin has more antigen presenting cells than muscle [78]. A new formulation of a serogroup $C$ vaccine was prepared for intradermal delivery using an immune stimulating complex emulsion. This produced a higher immune response than a comparable intramuscular injectible vaccine. Future work will apply the same techniques to other serogroups to further assess whether this route of delivery is a viable option.

\section{Perspectives and Future Outlook}

Targeted vaccines have been effective at reducing the public health burden of meningococcal meningitis across many regions of the globe. Glycoconjugate and now protein/OMV-based vaccines target most serogroups of $N$. meningitidis that cause disease. The work of basic researchers and clinical researchers have helped advance the field. This review has sought to describe the current meningococcal vaccines and new approaches for the future. Recent protein-based vaccines now target N. meningitidis serogroup B. A suitable strategy for this serogroup has been elusive for so long. Future work in protein-based vaccine discovery seeks to discover broadly protective protein targets. Lipooligosaccharides and outer membrane vesicles are also under investigation for new targets for a broadly protective vaccine. A number of glycoconjugate vaccines against $N$. meningitidis $\mathrm{A}, \mathrm{C}$, $\mathrm{W}$ and $\mathrm{Y}$ using conventional methods of vaccine production exist. New discoveries aim to create well-defined homogeneous vaccines for which the carbohydrate antigen structure-immunogenicity relationship can be better determined. These strategies use chemical and/or enzymatic methods to produce carbohydrates. However, to date there is only one glycoconjugate vaccine on the market containing a fully synthetic carbohydrate antigen. Quimi-Hib was licensed in Cuba in 2004 and targets Haemophilus influenza $\mathrm{b}[79,80]$. Progress in licensing of additional synthetic glycoconjugate vaccines has been slow.

In the case of meningococcal vaccines, one potential reason may lie in the difficulties of chemical and/or enzymatic synthesis. Many of the disease-causing polysaccharides (from serogroups A, B, C, $\mathrm{W}$ and $\mathrm{Y}$ ) are $\mathrm{O}$-acetylated at specific positions in vivo (Figure 1 ). These $\mathrm{O}$-acetyl groups may act to increase virulence and mask the antigen from immune cells [81]. This site-specific O-acetylation is challenging to recapitulate by strictly chemical methods (although possible, see Section 3.1) Enzymatic methods to produce O-acetylated polysaccharides require recombinant production of the proper O-acetyltransferases and capsule producing enzymes [82-84]. Enzymatic synthesis also 
requires significant time in the isolation of recombinant enzymes to sufficient purity and activity. Recently a one-pot chemoenzymatic synthetic approach was proposed to obtain O-acetylated sialic acid monomers however this has not been applied to oligomers [85]. Another barrier to success may be the iterative process that needs to take place in order to determine the proper epitope that can produce serogroup-specific bactericidal antibodies [86]. This time-consuming process involves (as described in Section 3.1) synthesis of various oligomer lengths, attachment to a carrier protein and assessment of the immune response generated. Recent advances have been made in improving the sensitivity and reliability of carbohydrate microarray technology so this method could be applied to N. meningitidis vaccine development in the future [87]. Microarrays could dramatically streamline the discovery process because carbohydrate antigens would first be chemically attached to a microarray plate and then tested for immune response using clinically derived serogroup-specific antibodies in a high-throughput format. Lastly, while chemical and enzymatic synthesis of meningococcal carbohydrate antigens have shown promise on the research-scale, these methods still need to be optimized to manufacturing-scale levels. Future advances built upon current foundations in solid-phase chemical synthesis, enzyme production and chemoenzymatic synthesis are needed to help drive vaccine development forward.

Carrier proteins are also critical components of homogenous vaccines. As discussed, recent studies have investigated novel carrier proteins to produce vaccine candidates. However these new proteins will require a substantial amount of laboratory and clinical studies to establish their safety and efficacy before use in glycoconjugate vaccines. In the short term, advanced mass spectrometry techniques can be used to specifically pinpoint sites where carrier proteins have been modified and carbohydrates have been conjugated $[46,88,89]$. New applications of site-specific conjugation methods to already established carrier proteins will also help facilitate production of homogenous vaccines [46]. In addition, further characterization of the effects inactivation has on a carrier protein will help provide more insight on the final structure in glycoconjugate vaccines [90]. In closing, there have been many recent scientific research advances that will positively impact meningococcal vaccine development so that new safe and effective vaccines can be brought to market faster. Most pressing for the immediate future, is development of a vaccine for $N$. meningitidis serogroup $\mathrm{X}$ as the prevalence of this serogroup is increasing [91] .

\section{Conclusions}

Vaccination strategies against meningococcal meningitis include polysaccharide, glycoconjugate, combined conjugate and protein/OMV based vaccines. These vaccines have been proven to be safe and effective against N. meningitidis serogroups A, B, C, W and Y. Glycoconjugate vaccines of the future will likely use approaches such as chemical/chemoenzymatic synthesis, advanced carrier protein characterization and site-specific conjugation chemistry to obtain homogeneous vaccines. These approaches are already underway in the development of a glycoconjugate vaccine for N. meningitidis serogroup $\mathrm{X}$ for which there is currently no protective vaccine.

Acknowledgments: The authors thank Willie Vann for reviewing the manuscript. Research in the McCarthy laboratory is supported in part by the National Institute of General Medical Sciences of the National Institutes of Health under Award Number UL1GM118973. The content is solely the responsibility of the authors and does not necessarily represent the official views of the National Institutes of Health.

Author Contributions: Pumtiwitt C. McCarthy, Abeer Sharyan, and Laleh Sheikhi Moghaddam performed literature searches and analyses. Pumtiwitt C. McCarthy, Abeer Sharyan, and Laleh Sheikhi Moghaddam wrote initial drafts of the manuscript. Pumtiwitt C. McCarthy wrote and edited the final draft of the manuscript.

Conflicts of Interest: The authors declare no conflict of interest.

\section{References}

1. World Health Organization. Meningococcal Meningitis Fact Sheet. Available online: http://www.who.int/ mediacentre/factsheets/fs141/en/ (accessed on 19 January 2018). 
2. Gasparini, R.; Panatto, D. Meningococcal glycoconjugate vaccines. Hum. Vaccin. 2011, 7, 170-182. [CrossRef] [PubMed]

3. Stephens, D.S. Conquering the meningococcus. FEMS Microbiol. Rev. 2007, 31, 3-14. [CrossRef] [PubMed]

4. Borrow, R.; Alarcon, P.; Carlos, J.; Caugant, D.A.; Christensen, H.; Debbag, R.; De Wals, P.; Echániz-Aviles, G.; Findlow, J.; Head, C.; et al. The Global Meningococcal Initiative: Global epidemiology, the impact of vaccines on meningococcal disease and the importance of herd protection. Expert. Rev. Vaccines 2017, 16, 313-328. [CrossRef] [PubMed]

5. Hedari, C.P.; Khinkarly, R.W.; Dbaibo, G.S. Meningococcal serogroups A, C, W-135, and Y tetanus toxoid conjugate vaccine: A new conjugate vaccine against invasive meningococcal disease. Infect. Drug Resist. 2014, 7, 85-99. [CrossRef] [PubMed]

6. Feavers, I.M.; Maiden, M.C.J. Recent Progress in the Prevention of Serogroup B Meningococcal Disease. Clin. Vaccine Immunol. 2017, 24. [CrossRef] [PubMed]

7. World Health Organization. Meningococcal Meninigitis: Emergency preparedness and response. Available online: http:/ / www.who.int/csr/disease/meningococcal/en/ (accessed on 19 January 2018).

8. Mitchison, N.A. The carrier effect in the secondary response to hapten-protein conjugates. II. Cellular cooperation. Eur. J. Immunol. 1971, 1, 18-27. [CrossRef] [PubMed]

9. Hutter, J.; Lepenies, B. Carbohydrate-Based Vaccines: An Overview. Methods Mol. Biol. 2015, 1331, 1-10. [PubMed]

10. Bardotti, A.; Averani, G.; Berti, F.; Berti, S.; Carinci, V.; D’Ascenzi, S.; Fabbri, B.; Giannini, S.; Giannozzi, A.; Magagnoli, C.; et al. Physicochemical characterisation of glycoconjugate vaccines for prevention of meningococcal diseases. Vaccine 2008, 26, 2284-2296. [CrossRef] [PubMed]

11. Pichichero, M.E. Protein carriers of conjugate vaccines: Characteristics, development, and clinical trials. Hum. Vaccin. Immunother. 2013, 9, 2505-2523. [CrossRef] [PubMed]

12. Singh, K.; Mehta, S. The clinical development process for a novel preventive vaccine: An overview. J. Postgrad. Med. 2016, 62, 4-11. [CrossRef] [PubMed]

13. LaForce, F.M.; Djingarey, M.; Viviani, S.; Preziosi, M.P. Lessons from the Meningitis Vaccine Project. Viral. Immunol. 2017. [CrossRef] [PubMed]

14. Frasch, C.E.; Kapre, S.V.; Lee, C.H.; Preaud, J.M. Technical Development of a New Meningococcal Conjugate Vaccine. Clin. Infect. Dis. 2015, 61, S404-S409. [CrossRef] [PubMed]

15. Papaevangelou, V.; Spyridis, N. MenACWY-TT vaccine for active immunization against invasive meningococcal disease. Expert. Rev. Vaccines 2012, 11, 523-537. [CrossRef] [PubMed]

16. Pellegrino, P.; Perrone, V.; Radice, S.; Capuano, A.; Clementi, E. Immunogenicity of meningococcal quadrivalent (serogroup A, C, W135 and Y) tetanus toxoid conjugate vaccine: Systematic review and meta-analysis. Pharmacol. Res. 2015, 92, 31-39. [CrossRef] [PubMed]

17. Tregnaghi, M.; Lopez, P.; Stamboulian, D.; Grana, G.; Odrljin, T.; Bedell, L.; Dull, P.M. Immunogenicity and safety of a quadrivalent meningococcal polysaccharide CRM conjugate vaccine in infants and toddlers. Int. J. Infect. Dis. 2014, 26, 22-30. [CrossRef] [PubMed]

18. Miller, J.M.; Mesaros, N.; Van Der Wielen, M.; Baine, Y. Conjugate Meningococcal Vaccines Development: GSK Biologicals Experience. Adv. Prev. Med. 2011. [CrossRef] [PubMed]

19. World Health Organization: Immunization, Vaccines and Biologicals-Haemophilus influenzae type b (Hib). Available online: http:/ / www.who.int/immunization/topics/hib/en/ (accessed on 30 January 2018).

20. Schneerson, R.; Robbins, J.B.; Chu, C.; Sutton, A.; Vann, W.; Vickers, J.C.; London, W.T.; Curfman, B.; Hardegree, M.C.; Shiloach, J.; et al. Serum antibody responses of juvenile and infant rhesus monkeys injected with Haemophilus influenzae type $b$ and pneumococcus type 6A capsular polysaccharide-protein conjugates. Infect. Immun. 1984, 45, 582-591. [PubMed]

21. McCoy, R.D.; Vimr, E.R.; Troy, F.A. CMP-NeuNAc:poly-alpha-2,8-sialosyl sialyltransferase and the biosynthesis of polysialosyl units in neural cell adhesion molecules. J. Biol. Chem. 1985, 260, 12695-12699. [PubMed]

22. Ashton, F.E.; Ryan, J.A.; Michon, F.; Jennings, H.J. Protective efficacy of mouse serum to the N-propionyl derivative of meningococcal group B polysaccharide. Microb. Pathog. 1989, 6, 455-458. [CrossRef]

23. Jennings, H.J.; Gamian, A.; Ashton, F.E. N-propionylated group B meningococcal polysaccharide mimics a unique epitope on group B Neisseria meningitidis. J. Exp. Med. 1987, 165, 1207-1211. [CrossRef] [PubMed] 
24. Jennings, H.J.; Roy, R.; Gamian, A. Induction of meningococcal group B polysaccharide-specific IgG antibodies in mice by using an N-propionylated B polysaccharide-tetanus toxoid conjugate vaccine. J. Immunol. 1986, 137, 1708-1713. [PubMed]

25. Krug, L.M.; Ragupathi, G.; Hood, C.; George, C.; Hong, F.; Shen, R.; Abrey, L.; Jennings, H.J.; Kris, M.G.; Livingston, P.O. Immunization with N-propionyl polysialic acid-KLH conjugate in patients with small cell lung cancer is safe and induces IgM antibodies reactive with SCLC cells and bactericidal against group B meningococci. Can. Immunol. Immunother. 2012, 61, 9-18. [CrossRef] [PubMed]

26. Sotolongo, F.; Campa, C.; Casanueva, V.; Fajardo, E.M.; Cuevas, I.E.; Gonzalez, N. Cuban Meningococcal BC Vaccine: Experiences \& Contributions from 20 Years of Application. MEDICC Rev. 2007, 9, 16-22. [PubMed]

27. Pizza, M.; Scarlato, V.; Masignani, V.; Giuliani, M.M.; Arico, B.; Comanducci, M.; Jennings, G.T.; Baldi, L.; Bartolini, E.; Capecchi, B.; et al. Identification of vaccine candidates against serogroup B meningococcus by whole-genome sequencing. Science 2000, 287, 1816-1820. [CrossRef] [PubMed]

28. Tettelin, H.; Saunders, N.J.; Heidelberg, J.; Jeffries, A.C.; Nelson, K.E.; Eisen, J.A.; Ketchum, K.A.; Hood, D.W.; Peden, J.F.; Dodson, R.J.; et al. Complete genome sequence of Neisseria meningitidis serogroup B strain MC58. Science 2000, 287, 1809-1815. [CrossRef] [PubMed]

29. Sette, A.; Rappuoli, R. Reverse vaccinology: Developing vaccines in the era of genomics. Immunity 2010, 33, 530-541. [CrossRef] [PubMed]

30. Adamo, R. Advancing Homogeneous Antimicrobial Glycoconjugate Vaccines. Acc. Chem. Res. 2017, 50, 1270-1279. [CrossRef] [PubMed]

31. Frasch, C.E. Preparation of bacterial polysaccharide-protein conjugates: Analytical and manufacturing challenges. Vaccine 2009, 27, 6468-6470. [CrossRef] [PubMed]

32. Gao, Q.; Zaccaria, C.; Tontini, M.; Poletti, L.; Costantino, P.; Lay, L. Synthesis and preliminary biological evaluation of carba analogues from Neisseria meningitidis A capsular polysaccharide. Org. Biomol. Chem. 2012, 10, 6673-6681. [CrossRef] [PubMed]

33. Borrow, R.; Balmer, P.; Miller, E. Meningococcal surrogates of protection—serum bactericidal antibody activity. Vaccine 2005, 23, 2222-2227. [CrossRef] [PubMed]

34. Wang, C.H.; Li, S.T.; Lin, T.L.; Cheng, Y.Y.; Sun, T.H.; Wang, J.T.; Cheng, T.J.; Mong, K.K.; Wong, C.H. Synthesis of Neisseria meningitidis serogroup W135 capsular oligosaccharides for immunogenicity comparison and vaccine development. Angew. Chem. Int. Ed. Engl. 2013, 52, 9157-9161. [CrossRef] [PubMed]

35. Harale, K.R.; Rout, J.K.; Chhikara, M.K.; Gill, D.S.; Misra, A.K. Synthesis and immunochemical evaluation of a novel Neisseria meningitidis serogroup A tetrasaccharide and its conjugate. Org. Chem. Front. 2017, 4, 2348-2357. [CrossRef]

36. Liao, G.; Zhou, Z.; Guo, Z. Synthesis and immunological study of alpha-2,9-oligosialic acid conjugates as anti-group C meningitis vaccines. Chem. Commun. (Camb) 2015, 51, 9647-9650. [CrossRef] [PubMed]

37. Freiberger, F.; Claus, H.; Gunzel, A.; Oltmann-Norden, I.; Vionnet, J.; Muhlenhoff, M.; Vogel, U.; Vann, W.F.; Gerardy-Schahn, R.; Stummeyer, K. Biochemical characterization of a Neisseria meningitidis polysialyltransferase reveals novel functional motifs in bacterial sialyltransferases. Mol. Microbiol. 2007, 65, 1258-1275. [CrossRef] [PubMed]

38. Peterson, D.C.; Arakere, G.; Vionnet, J.; McCarthy, P.C.; Vann, W.F. Characterization and acceptor preference of a soluble meningococcal group C polysialyltransferase. J. Bacteriol. 2011, 193, 1576-1582. [CrossRef] [PubMed]

39. Romanow, A.; Haselhorst, T.; Stummeyer, K.; Claus, H.; Bethe, A.; Muhlenhoff, M.; Vogel, U.; von Itzstein, M.; Gerardy-Schahn, R. Biochemical and biophysical characterization of the sialyl-/hexosyltransferase synthesizing the meningococcal serogroup W135 heteropolysaccharide capsule. J. Biol. Chem. 2013, 288, 11718-11730. [CrossRef] [PubMed]

40. Fiebig, T.; Berti, F.; Freiberger, F.; Pinto, V.; Claus, H.; Romano, M.R.; Proietti, D.; Brogioni, B.; Stummeyer, K.; Berger, M.; et al. Functional expression of the capsule polymerase of Neisseria meningitidis serogroup X: A new perspective for vaccine development. Glycobiology 2014, 24, 150-158. [CrossRef] [PubMed]

41. Fiebig, T.; Freiberger, F.; Pinto, V.; Romano, M.R.; Black, A.; Litschko, C.; Bethe, A.; Yashunsky, D.; Adamo, R.; Nikolaev, A.; et al. Molecular cloning and functional characterization of components of the capsule biosynthesis complex of Neisseria meningitidis serogroup A: Toward in vitro vaccine production. J. Biol. Chem. 2014, 289, 19395-19407. [CrossRef] [PubMed] 
42. Muindi, K.M.; McCarthy, P.C.; Wang, T.; Vionnet, J.; Battistel, M.; Jankowska, E.; Vann, W.F. Characterization of the meningococcal serogroup X capsule $\mathrm{N}$-acetylglucosamine-1-phosphotransferase. Glycobiology 2014, 24, 139-149. [CrossRef] [PubMed]

43. Romanow, A.; Keys, T.G.; Stummeyer, K.; Freiberger, F.; Henrissat, B.; Gerardy-Schahn, R. Dissection of hexosyl- and sialyltransferase domains in the bifunctional capsule polymerases from Neisseria meningitidis W and Y defines a new sialyltransferase family. J. Biol. Chem. 2014, 289, 33945-33957. [CrossRef] [PubMed]

44. Ming, S.A.; Cottman-Thomas, E.; Black, N.C.; Chen, Y.; Veeramachineni, V.; Peterson, D.C.; Chen, X.; Tedaldi, L.M.; Wagner, G. K.; Cai, C.; et al. Interaction of Neisseria meningitidis Group X $\mathrm{N}$-acetylglucosamine-1-phosphotransferase with its donor substrate. Glycobiology 2018, 28, 100-107. [CrossRef] [PubMed]

45. Mosley, S.L.; Rancy, P.C.; Peterson, D.C.; Vionnet, J.; Saksena, R.; Vann, W.F. Chemoenzymatic synthesis of conjugatable oligosialic acids. Biocatal. Biotransformation. 2010, 28, 41-50. [CrossRef]

46. McCarthy, P.C.; Saksena, R.; Peterson, D.C.; Lee, C.H.; An, Y.; Cipollo, J.F.; Vann, W.F. Chemoenzymatic synthesis of immunogenic meningococcal group $\mathrm{C}$ polysialic acid-tetanus Hc fragment glycoconjugates. Glycoconj. J. 2013, 30, 857-870. [CrossRef] [PubMed]

47. Fiebig, T.; Romano, M.R.; Oldrini, D.; Adamo, R.; Tontini, M.; Brogioni, B.; Santini, L.; Berger, M.; Costantino, P.; Berti, F.; et al. An efficient cell free enzyme-based total synthesis of a meningococcal vaccine candidate. NPJ Vaccines 2016, 1. [CrossRef] [PubMed]

48. Fiebig, T.; Litschko, C.; Freiberger, F.; Bethe, A.; Berger, M.; Gerardy-Schahn, R. Efficient solid-phase synthesis of meningococcal capsular oligosaccharides enables simple and fast chemoenzymatic vaccine production. J. Biol. Chem. 2017. [CrossRef] [PubMed]

49. Varki, A.; Cummings, R.D.; Aebi, M.; Packer, N.H.; Seeberger, P.H.; Esko, J.D.; Stanley, P.; Hart, G.; Darvill, A.; Kinoshita, T.; et al. Symbol Nomenclature for Graphical Representations of Glycans. Glycobiology 2015, 25, 1323-1324. [CrossRef] [PubMed]

50. Tontini, M.; Romano, M.R.; Proietti, D.; Balducci, E.; Micoli, F.; Balocchi, C.; Santini, L.; Masignani, V.; Berti, F.; Costantino, P. Preclinical studies on new proteins as carrier for glycoconjugate vaccines. Vaccine 2016, 34, 4235-4242. [CrossRef] [PubMed]

51. Cox, A.D.; St Michael, F.; Neelamegan, D.; Lacelle, S.; Cairns, C.; Richards, J.C. Investigating the candidacy of LPS-based glycoconjugates to prevent invasive meningococcal disease: Chemical strategies to prepare glycoconjugates with good carbohydrate loading. Glycoconj. J. 2010, 27, 401-417. [CrossRef] [PubMed]

52. Reinhardt, A.; Yang, Y.; Claus, H.; Pereira, C.L.; Cox, A.D.; Vogel, U.; Anish, C.; Seeberger, P.H. Antigenic potential of a highly conserved Neisseria meningitidis lipopolysaccharide inner core structure defined by chemical synthesis. Chem. Biol. 2015, 22, 38-49. [CrossRef] [PubMed]

53. Gerritzen, M.J.H.; Martens, D.E.; Wijffels, R.H.; van der Pol, L.; Stork, M. Bioengineering bacterial outer membrane vesicles as vaccine platform. Biotechnol. Adv. 2017, 35, 565-574. [CrossRef] [PubMed]

54. Christodoulides, M.; Heckels, J. Novel approaches to Neisseria meningitidis vaccine design. Pathog. Dis. 2017. [CrossRef] [PubMed]

55. Pajon, R.; Fergus, A.M.; Granoff, D.M. Mutant Native Outer Membrane Vesicles Combined with a Serogroup A Polysaccharide Conjugate Vaccine for Prevention of Meningococcal Epidemics in Africa. PLoS ONE 2013, 8, e66536. [CrossRef] [PubMed]

56. Van de Waterbeemd, B.; Streefland, M.; van der Ley, P.; Zomer, B.; van Dijken, H.; Martens, D.; Wijffels, R.; van der Pol, L. Improved OMV vaccine against Neisseria meningitidis using genetically engineered strains and a detergent-free purification process. Vaccine 2010, 28, 4810-4816. [CrossRef] [PubMed]

57. Jolley, K.A.; Brehony, C.; Maiden, M.C. Molecular typing of meningococci: Recommendations for target choice and nomenclature. FEMS Microbiol. Rev. 2007, 31, 89-96. [CrossRef] [PubMed]

58. Dull, P.M.; McIntosh, E.D. Meningococcal vaccine development-from glycoconjugates against MenACWY to proteins against MenB-potential for broad protection against meningococcal disease. Vaccine 2012, 30, B18-B25. [CrossRef] [PubMed]

59. Matthias, K.A.; Strader, M.B.; Nawar, H.F.; Gao, Y.S.; Lee, J.; Patel, D.S.; Im, W.; Bash, M.C. Heterogeneity in non-epitope loop sequence and outer membrane protein complexes alters antibody binding to the major porin protein PorB in serogroup B Neisseria meningitidis. Mol. Microbiol. 2017, 105, 934-953. [CrossRef] [PubMed] 
60. Hung, M.C.; Salim, O.; Williams, J.N.; Heckels, J.E.; Christodoulides, M. The Neisseria meningitidis macrophage infectivity potentiator protein induces cross-strain serum bactericidal activity and is a potential serogroup B vaccine candidate. Infect. Immun. 2011, 79, 3784-3791. [CrossRef] [PubMed]

61. Bielecka, M.K.; Devos, N.; Gilbert, M.; Hung, M.C.; Weynants, V.; Heckels, J.E.; Christodoulides, M. Recombinant protein truncation strategy for inducing bactericidal antibodies to the macrophage infectivity potentiator protein of Neisseria meningitidis and circumventing potential cross-reactivity with human FK506-binding proteins. Infect. Immun. 2015, 83, 730-742. [CrossRef] [PubMed]

62. Costoya, L.; Marzoa, J.; Ferreiros, C.; Criado, M.T. Liposomes or traditional adjuvants: Induction of bactericidal activity by the macrophage infectivity potentiator protein (Mip) of Neisseria meningitidis. Apmis 2017, 125, 725-731. [CrossRef] [PubMed]

63. Hung, M.C.; Heckels, J.E.; Christodoulides, M. The adhesin complex protein (ACP) of Neisseria meningitidis is a new adhesin with vaccine potential. MBio 2013, 4. [CrossRef] [PubMed]

64. Hung, M.C.; Humbert, M.V.; Laver, J.R.; Phillips, R.; Heckels, J.E.; Christodoulides, M. A putative amino acid ABC transporter substrate-binding protein, NMB1612, from Neisseria meningitidis, induces murine bactericidal antibodies against meningococci expressing heterologous NMB1612 proteins. Vaccine 2015, 33, 4486-4494. [CrossRef] [PubMed]

65. Delgado, M.; Yero, D.; Niebla, O.; Gonzalez, S.; Climent, Y.; Perez, Y.; Cobas, K.; Caballero, E.; Garcia, D.; Pajon, R. Lipoprotein NMB0928 from Neisseria meningitidis serogroup B as a novel vaccine candidate. Vaccine 2007, 25, 8420-8431. [CrossRef] [PubMed]

66. Sardinas, G.; Yero, D.; Climent, Y.; Caballero, E.; Cobas, K.; Niebla, O. Neisseria meningitidis antigen NMB0088: Sequence variability, protein topology and vaccine potential. J. Med. Microbiol. 2009, 58, 196-208. [CrossRef] [PubMed]

67. Mistretta, N.; Guy, B.; Berard, Y.; Dalencon, F.; Fratantonio, O.; Gregoire, C.; Lechevallier, A.; Lheritier, P.; Revet, L.; Moreau, M.; et al. Improvement of immunogenicity of meningococcal lipooligosaccharide by coformulation with lipidated transferrin-binding protein B in liposomes: Implications for vaccine development. Clin. Vaccine Immunol. 2012, 19, 711-722. [CrossRef] [PubMed]

68. Freixeiro, P.; Dieguez-Casal, E.; Costoya, L.; Seijo, B.; Ferreiros, C.M.; Criado, M.T.; Sanchez, S. Study of the stability of proteoliposomes as vehicles for vaccines against Neisseria meningitidis based on recombinant porin complexes. Int. J. Pharm. 2013, 443, 1-8. [CrossRef] [PubMed]

69. Maharjan, S.; Saleem, M.; Feavers, I.M.; Wheeler, J.X.; Care, R.; Derrick, J.P. Dissection of the function of the RmpM periplasmic protein from Neisseria meningitidis. Microbiology 2016, 162, 364-375. [CrossRef] [PubMed]

70. Phillips, R.; Williams, J.N.; Tan, W.M.; Bielecka, M.K.; Thompson, H.; Hung, M.C.; Heckels, J.E.; Christodoulides, M. Immunization with recombinant Chaperonin60 (Chp60) outer membrane protein induces a bactericidal antibody response against Neisseria meningitidis. Vaccine 2013, 31, 2584-2590. [CrossRef] [PubMed]

71. Gregory, A.; Williamson, D.; Titball, R. Vaccine delivery using nanoparticles. Front. Cell. Infect. Microbiol. 2013. [CrossRef] [PubMed]

72. Arenas, J.; van Dijken, H.; Kuipers, B.; Hamstra, H.J.; Tommassen, J.; van der Ley, P. Coincorporation of LpxL1 and PagL mutant lipopolysaccharides into liposomes with Neisseria meningitidis opacity protein: Influence on endotoxic and adjuvant activity. Clin. Vaccine Immunol. 2010, 17, 487-495. [CrossRef] [PubMed]

73. De Jonge, M.I.; Hamstra, H.J.; Jiskoot, W.; Roholl, P.; Williams, N.A.; Dankert, J.; van Alphen, L.; van der Ley, P. Intranasal immunisation of mice with liposomes containing recombinant meningococcal OpaB and OpaJ proteins. Vaccine 2004, 22, 4021-4028. [CrossRef] [PubMed]

74. Freixeiro, P.; Dieguez-Casal, E.; Costoya, L.; Marzoa, J.; Ferreiros, C.M.; Criado, M.T.; Sanchez, S. High resolution clear native electrophoresis (hrCNE) allows a detailed analysis of the heterotrimeric structure of recombinant Neisseria meningitidis porins inserted into liposomes. J. Proteome. Res. 2013, 12, 777-784. [CrossRef] [PubMed]

75. Sanchez, S.; Abel, A.; Marzoa, J.; Gorringe, A.; Criado, T.; Ferreiros, C.M. Characterisation and immune responses to meningococcal recombinant porin complexes incorporated into liposomes. Vaccine 2009, 27, 5338-5343. [CrossRef] [PubMed]

76. Del Tordello, E.; Danilchanka, O.; McCluskey, A.J.; Mekalanos, J.J. Type VI secretion system sheaths as nanoparticles for antigen display. Proc. Natl. Acad. Sci. USA 2016, 113, 3042-3047. [CrossRef] [PubMed] 
77. Donadei, A.; Balocchi, C.; Romano, M.R.; Panza, L.; Adamo, R.; Berti, F.; O’Hagan, D.T.; Gallorini, S.; Baudner, B.C. Optimizing adjuvants for intradermal delivery of MenC glycoconjugate vaccine. Vaccine 2017, 35, 3930-3937. [CrossRef] [PubMed]

78. Liang, F.; Lore, K. Local innate immune responses in the vaccine adjuvant-injected muscle. Clin. Transl. Immunol. 2016, 5. [CrossRef] [PubMed]

79. Verez-Bencomo, V.; Fernández-Santana, V.; Hardy, E.; Toledo, M.E.; Rodríguez, M.C.; Heynngnezz, L.; Rodriguez, A.; Baly, A.; Herrera, L.; Izquierdo, M.; et al. A Synthetic Conjugate Polysaccharide Vaccine Against Haemophilus influenzae Type b. Science. 2004, 305, 522-555. [CrossRef] [PubMed]

80. Toraño, G.; Toledo, M.E.; Baly, A.; Fernandez-Santana, V.; Rodriguez, F.; Alvarez, Y.; Serrano, T.; Musachio, A.; Hernandez, I.; Hardy, E.; et al. Phase I Clinical Evaluation of a Synthetic Oligosaccharide-Protein Conjugate Vaccine against Haemophilus influenzae Type b in Human Adult Volunteers. Clin. Vaccine Immunol. 2006, 13, 1052-1056. [CrossRef] [PubMed]

81. Fusco, P.C.; Farley, E.K.; Huang, C.H.; Moore, S.; Michon, F. Protective meningococcal capsular polysaccharide epitopes and the role of $\mathrm{O}$ acetylation. Clin. Vaccine Immunol. 2007, 14, 577-584. [CrossRef] [PubMed]

82. Bergfeld, A.K.; Claus, H.; Lorenzen, N.K.; Spielmann, F.; Vogel, U.; Muhlenhoff, M. The polysialic acid-specific O-acetyltransferase OatC from Neisseria meningitidis serogroup C evolved apart from other bacterial sialate O-acetyltransferases. J. Biol. Chem. 2009, 284, 6-16. [CrossRef] [PubMed]

83. Gudlavalleti, S.K.; Datta, A.K.; Tzeng, Y.L.; Noble, C.; Carlson, R.W.; Stephens, D.S. The Neisseria meningitidis serogroup A capsular polysaccharide O-3 and O-4 acetyltransferase. J. Biol. Chem. 2004, 279, 42765-42773. [CrossRef] [PubMed]

84. Lee, H.J.; Rakic, B.; Gilbert, M.; Wakarchuk, W.W.; Withers, S.G.; Strynadka, N.C. Structural and kinetic characterizations of the polysialic acid O-acetyltransferase OatWY from Neisseria meningitidis. J. Biol. Chem. 2009, 284, 24501-24511. [CrossRef] [PubMed]

85. Khedri, Z.; Xiao, A.; Yu, H.; Landig, C.S.; Li, W.; Diaz, S.; Wasik, B.R.; Parrish, C.R.; Wang, L.P.; Varki, A.; et al. A Chemical Biology Solution to Problems with Studying Biologically Important but Unstable 9-O-Acetyl Sialic Acids. ACS Chem. Biol. 2017, 12, 214-224. [CrossRef] [PubMed]

86. Anish, C.; Schumann, B.; Pereira, C.L.; Seeberger, P.H. Chemical Biology Approaches to Designing Defined Carbohydrate Vaccines. Chem. Biol. 2014, 21, 38-50. [CrossRef] [PubMed]

87. Hyun, J.Y.; Pai, J.; Shin, I. The Glycan Microarray Story from Construction to Applications. Acc. Chem. Res. 2017, 50, 1069-1078. [CrossRef] [PubMed]

88. Moginger, U.; Resemann, A.; Martin, C.E.; Parameswarappa, S.; Govindan, S.; Wamhoff, E.C.; Broecker, F.; Suckau, D.; Pereira, C. L.; Anish, C.; et al. Cross Reactive Material 197 glycoconjugate vaccines contain privileged conjugation sites. Sci. Rep. 2016, 6. [CrossRef] [PubMed]

89. Jahouh, F.; Xu, P.; Vann, W.F.; Kovac, P.; Banoub, J.H. Mapping the glycation sites in the neoglycoconjugate from hexasaccharide antigen of Vibrio cholerae, serotype Ogawa and the recombinant tetanus toxin C-fragment carrier. J. Mass Spectrom. 2013, 48, 1083-1090. [CrossRef] [PubMed]

90. Bayart, C.; Peronin, S.; Jean, E.; Paladino, J.; Talaga, P.; Borgne, M.L. The combined use of analytical tools for exploring tetanus toxin and tetanus toxoid structures. J. Chromatogr. B Analyt. Technol. Biomed. Life Sci. 2017, 1054, 80-92. [CrossRef] [PubMed]

91. Xie, O.; Pollard, A.J.; Mueller, J.E.; Norheim, G. Emergence of serogroup X meningococcal disease in Africa: Need for a vaccine. Vaccine 2013, 31, 2852-2861. [CrossRef] [PubMed]

(C) 2018 by the authors. Licensee MDPI, Basel, Switzerland. This article is an open access article distributed under the terms and conditions of the Creative Commons Attribution (CC BY) license (http://creativecommons.org/licenses/by/4.0/). 